\title{
Shared Value Creation in Australian Insurance Industry: The Qualitative Case Studies of IAG and AIA
}

\author{
Asoke Rocky Mehera, Lecturer in Business.
}

Address: Level 7, 250 Collins Street, Melbourne, Australia, Victoria 3000.

\begin{abstract}
This study explores the societal and economic value creation by large Australian insurance organisations, which integrate 'shared value' business model into their core business. The research objective of this paper is to explore the adoption of three value-enhancing thematic components of the applied shared value model, which are reconceiving products and markets, redefining productivity in the value chain and enabling local cluster development, by two Australian insurance organisations. Using case study design, the thematic analysis of primary interview data reflects how Insurance Australia Group (IAG) and American International Assurance (AIA Australia) have utilised the shared value model to create social value while generating economic value. The secondary findings also identify a fundamental shift in the customer value propositions within the conventional insurance industry, demonstrating successful utilisation of shared value model. The findings will help future academic researchers and practice managers to understand the evolving thematic components of value creation operating within the Australian insurance industry.
\end{abstract}

Keywords: Shared Value, Australian Insurance Industry, Qualitative Case Study

DOI: $10.7176 / \mathrm{EJBM} / 11-30-09$

Publication date:October $31^{\text {st }} 2019$

\section{Introduction}

Conventional health and general insurance have evolved around risk mitigation and post-event support and recovery. In Australia, the notion of value-based insurance gained momentum in the post-Global Financial Crisis (post-GFC) arising primarily from the strategic initiatives put forward by Insurance Australia Group (IAG) and American International Assurance (AIA Australia). Leveraging on the shared value model, the sampled Australian insurance organisations formulated their business model for value creation based on health awareness, prevention and community resilience. Actually, the "re-configuration of business models and products/services to deliver unique solutions to societal needs" (Jais et al. 2017, p. 9) has gained momentum in Australian insurance industry context. In fact, based on a superior customer value proposition, the present study illustrates that the application of the shared value model has lead to enhancement of economic value for the business and at the same time increase of social value (alongwith risk reduction) for customers and communities.

\section{Current state of the Australian insurance industry}

For improving community safety and economic stability based on lower premiums, the Insurance Council of Australia (2017) has attracted attention toward the following aspect: "The relative imbalance between funding for disaster response activities compared with disaster mitigation is a longstanding economic failure in Australia, and a systemic approach is required to reduce existing community exposures" (Accenture 2017, p. 3). "The Australian' newspaper (Scott, 2019) has already reported insurance risk associated with climate change in terms as follows: "Rising insurance premiums in northern Australia is threatening the communities that face natural disasters and Government needs to improve infrastructure to better protect communities and alleviate pressure on insurers" (p. 21). Hence, some of the Australian insurers have started to make their products "more flexible and customised while introducing low-cost distribution channels to minimise expenses" (Wu 2017, p. 11).

Two main trends driving long-term changes in the Australian insurance industry are (1) product and service comparability to support consumer understanding and specific needs, and (2) industry consolidation and rising premiums (Price Waterhouse Coopers, 2017). There is no doubt, despite the insurance innovation (especially health), overall consumer concerns about the economy led to an increase in discounted insurance plans and brand 
switching in 2017 (Accenture, 2017). The interplay of economic, regulatory and market shifts are expected to reset strategic imperatives for internal and external transformation with priorities including (1) customer-centric strategy based on understanding needs of key customer segment, (2) digital innovation-driven performance based on reinventing customer interaction and utilising data analytics across the value chain, and (3) reconfiguring business strategies based on positioning (Ernst \& Young, 2017).

The Health Insurance Amendment Act 2012 contributed to the adoption of an industry-wide approach to making health insurance easier to understand and facilitating information-sharing between consumers and insurers. In the medium to longer term, growth in the Australian healthcare industry has moved from benefiting the growing and ageing population to an increased focus on obesity and chronic diseases and consequently increasing the demand for medical treatment. Furthermore, in Australia, the radical transformation of the insurance industry is largely driven by automated business models to cater for the on-demand personalised insurance lifestyle products with direct-to-consumer digital interface (Australian and New Zealand Institute of Insurance and Finance 2019).

The abovementioned industry- reports identify two priority areas for the industry, namely, customer-centric strategy and flexible customised general and health insurance. To further explore the aspect of value creation in the Australian insurance industry, the shared value literature is reviewed below.

\section{Literature Review}

The ideology of creating business competitiveness based on the integration of social issues (Porter and Kramer 2006), had paved the way for the emergence of the 'shared value model' (Porter and Kramer 2011). Shared value is defined as "policies and operating practices enhancing the competitiveness of a company while simultaneously advancing the economic and social conditions in communities" (Porter \& Kramer 2011, p. 76).

Markets are increasingly defined by "creating economic value in a way that also creates value for society" (Porter and Kramer 2011, p. 64). As a competitive business strategy for solving pressing social problems, the shared value model emphasises the need to cater to the under-served markets. For long-term maximisation of value, Porter and Kramer (2011) identified "points of intersection between the company and society" (p. 91) based on both insideout and outside-in linkages influencing social networks, value chains, productivity and competitiveness. Harvard academics have proposed shared value as a parallel process of value creation through a "strategic win-win management model, which reconciles social benefits (relative to projected costs) and profit maximisation while utilising skills, resources, and management capabilities" (Porter \& Kramer, 2011, pp. 76-77). In promoting a shared value philosophy, shared value academics (Kania and Kramer, 2011; Kramer and Pfizer, 2016) have emphasised the collaboration of organisational ecosystems and the collective impact movement for value chain resilience and society-based innovation to counter market and social failure.

In the post-GFC era, shared value terminology is interpreted differently by academics, for instance to name a few, value for shareholders and stakeholders (Verboven, 2011), mission-based perspective (Maltz and Schein, 2012) and balancing social and financial value creation (Pirson, 2012). In short, the shared value literature emphasises the creation of new business strategies that integrate social and environmental issues as a means to improve longterm growth prospects and/or the competitiveness of firms.

Based on the above-mentioned literature review of the shared value concept, this study explores whether the selected insurance organisations leveraged shared value as a strategic model to cater for both economic and social aspects using a win-win lens of value creation. However, it is noted that Australia has limited shared value literature reviews. The Australian papers, namely Shared Value Green Paper (Leth \& Hems, 2013) and Shared Value Survey Report (Shared Value Project, 2015) just briefly depicts a few of shared value initiatives of AIA Australia and Insurance Australia Group. These reports do not explain the shared value framework of both the organisations applying three thematic components of shared value. Above all, organisational experts suggested significant changes to business practices to meet stakeholder expectations of sustainable profitability (Evans, 2007). This suggests that shared value aspect in Australian insurance industry needs to be further explored to understand the framework of shared value creation.

To address the above-mentioned research gap, a research question is framed as follows: "Why and how have Australian insurance organisations integrate the 'shared value' business model into their core business?" 


\section{Application of shared value model in the insurance industry}

The Shared Value business model consists of three strategic levels (Porter \& Kramer, 2011):

(1) Reconceiving products and markets - upgrading value propositions for satisfying unmet social needs by embedding social dimensions into the commercial product,

(2) Redefining productivity in the value chain - investing in socio-economic challenges because they impose economic costs, such as those affecting inputs, resource utilisation or operating efficiency, on the firm's value chain, and

(3) Enabling local cluster development - supporting the development of infrastructure to address broader socioeconomic issues, resulting in a stronger operating environment and competitiveness for an industry or market.

The value-creation framework for health insurance depends on the public infrastructure of the specific country, within which private insurance providers strive to fill welfare gaps through general and health insurance. In the post-GFC era, sustainable value-enhancing organisations strived for catering customer demand for affordable, streamlined and transparent services. For example, Suncorp and Good Shepherd Microfinance introduced 'Essentials by AAI' (2015), which offers car and home contents insurance on the same policy for qualifying customers, with flexible payment options and can be paid through the Centrepay system based on deductions from welfare payments (AAI Limited 2015). Suncorp bank has partnered with Good Shepherd Microfinance to create and distribute affordable car and home contents products for low-income earners, costing as little as A $\$ 4$ per week (Jais et al., 2017).

The Foundation Social Group (Jais et al., 2015) noted that the main global themes in the industry, in terms of shared value strategies are twofold: (1) close the protection gap for under-served markets, and (2) invest assets in prevention and protection systems. The strategies tend to align with redefining productivity in the value chain, as it typically involves customer-specific measures to reduce insurance events and claims. Closing the protection gap aligns with reconceiving products and markets, for example, the Suncorp Essentials product from AAI is creates a new offering for a market that has traditionally not been served because of affordability issues. The enabling of local cluster development is highlighted in Zurich Insurance's approach to addressing the whole-of-community level rather than just its own customers (Jais et al., 2015). These approaches are driving innovation through crossfunctional and cross-sectoral collaborations with the aim of creating financial returns while improving economic and social outcomes.

In some cases, non-traditional insurance organisations are striving to attract people from higher-risk pools by providing superior health technology, analysing customer health data and utilising partnerships with community and medical stakeholders (Christie et al., 2016), which in effect reduced the number of unhealthy days per year. Similar principles are being applied to driver behaviour and risk reduction. Prevention work, based on modern health and automobile technology across the entire value chain, is helping to close the protection gap for the community and reduce accident rates among riskier population segments (Selwyn et al., 2015).

A fundamental shift in the insurance value proposition emanates from the fact that insurers benefit from tackling the pressing customer issues and societal needs affecting their businesses. The strategy of investing in prevention and protection systems leads to reductions in payout claims and higher net returns for the company (Vitality Institute, 2016). Hence, Australian insurance organisations have started to experiment with value-based health insurance by forming an innovative alliance with South African Discovery Insurance, which tracks physical activity and nutrition as a basis for providing discounts from partner health grocery stores, gyms and diagnostic pathology centres (McKinsey, 2015).

To measure the impact of business activities on health care is carried out from three perspectives: (1) within the workplace through employee health and wellbeing, (2) in the marketplace through products and services, and (3) in the community through health, resilience and infrastructural investments (Vitality Institute, 2016). For example, shared value principles applied to insurance strategies create incentives for beneficiaries to improve their health and lifestyle, which in turn unlocks value for organisations through the broader prevention and protection of health or safety ecosystems. Employing behaviour-based pricing for customers and outcome-based costing of medical practitioners, "a virtuous cycle between risk reduction and value creation" (Jais et al. 2017, p. 8) is commenced. Another perspective on insurance strategies that create shared value, focusses on inclusive propositions, that is ensuring insurance literacy and providing affordable solutions to under-served communities.

The three-dimensional strategic model for identifying shared value opportunities involve (1) profitable business strategies through investment in preventable disease management and closing the protection gap, (2) meeting 
societal needs through urban and rural resilience for healthier and safer living, and (3) new corporate capabilities through value-chain partnerships (Jais et al., 2017).

The societal needs are re-framed to deliver healthier and safer urban living, secure rural livelihoods and disaster resilience (crop and casualty insurance). Innovation in personalised health technologies and advances in behavioural economics have contributed to improving health behaviours for chronic disease prevention (Gore, 2015). In fact, insurance innovation and data sharing across the insurance value chain is becoming much more essential for tracking customer progress, increasing insurance literacy and lowering the cost of premiums and claim payments.

In order for the Australian insurance industry to tap into the potential of shared value, its financial position is promoted based on four components: (1) economic resources — income, savings, debt management and ability to meet the cost of living, (2) financial products and services - demand and access to a bank account, credit and insurance, (3) financial knowledge and behaviour - confidence using financial and insurance products/services and willingness to seek financial advice, and (4) social capital - level of support from community, private and government networks (Australian Securities and Investment Commission, 2017).

Following the discussion on the application of shared value model in the insurance industry, the following research methodology is adopted based on an exploratory method.

\section{Research Methodology}

This study adopted the case design approach as it "allows investigators to examine real-life events over time, such as organisational and managerial processes and the maturation of industries" (Yin, 2009, p. 4). Both the selected organisations - IAG and AIA Insurance are active members of a common platform called 'Shared Value Project Australia' (Shared Value Project, 2015) and have won several awards for corporate social responsibility and sustainability initiatives. Information about the selected organisations is gathered from their websites and the Business Council Australia, Insurance Council Australia, Australian Bureau of Statistics, Shared Value Project Australia and Australian Centre for Corporate Social Responsibility.

Thematic analysis is actually used in primary qualitative research for identifying, analysing, and reporting patterns and themes within data set (Gibson \& Brown, 2009) based on commonalities, differences and relationships. From the primary interview data, and comparing with secondary data, various themes are identified in relation to the organisational initiatives for shared value creation based upon five major themes: 1) shared value themes - namely, re-conceiving products and markets, re-defining value chain and enabling local clusters, and 2) interviewfacilitated newly emerged themes - namely, customer/stakeholder engagement and community resilience.

The study explored how the shared value model is applied by IAG and AIA at the product/services, supply chain and cluster levels through both the secondary (i.e. organisational report) and primary (i.e. interview) source analysis. In-depth interviews were conducted in a semi-structured, open-ended, face-to-face and one-to-one context with shared value and corporate communications managers of IAG and AIA respectively. Following the interviews, primary data are compared with secondary data to validate the research (Stavros \& Westberg, 2009).

A comprehensive review of secondary resources are conducted below based on the organisational reports of IAG and AIA Insurance.

\section{Secondary Resource: IAG Report Analysis}

The IAG Annual Review and Sustainability Report states that "Our purpose is to make your world a safer place and we are committed to exploring opportunities to use technology for achieving this purpose and help mitigate the risk of loss for our customers and the wider community" (IAG 2017a, p. 1). The report identifies seven material issues: (1) reconfiguring business capabilities to cater customer needs and enhance experience, (2) innovative sustainable product development in future, (3) disaster education and affordable access for the underinsured, (4) community preparedness and resilience, (5) financial performance for shareholders while catering stakeholder interests, (6) transition to low-carbon economy) and (7) organisational purpose aligned to commercial success. To ensure future success, IAG has adopted a strategy "of embracing innovation to prepare for a future where customers' needs are based on experiences rather than products" (IAG 2017a, p. 4). To support this strategy, IAG 
is creating an agile organisation using innovative organisational design and an interactive operational mechanism to cater for emerging customer needs.

The adoption of various components of sustainable development goals (inclusive growth, resilient infrastructure, sustainable transport etc.) within its sustainability framework is reiterated in the 2017 annual report of NRMA Insurance, a subsidiary of IAG. In contrast, the Annual Review and Sustainability Report identifies a shared value mechanism: "Our shared value approach has provided a model to address social problems that address the expectations of society and provide commercial opportunity for IAG" (IAG 2017a, p. 15). The shared value model of IAG includes three aspects - safer, stronger, and more confident communities (IAG, 2017a).

One avenue for shared value creation is through innovative technological collaboration within a clustered environment. IAG not only collaborated with car manufacturers to improve the security and safety standards of vehicles, but also identified dangerous crash zones and engaged local governments for infrastructure development. IAG's virtual-reality technology has helped prospective home-buyers and renters identify and address hazards, while also increasing inquiry rates for its home insurance products.

IAG's process for creating shared value draws upon a range of broader capabilities, including product innovation that anticipates or enhances customer needs, collaborative partnerships with new types of organisations, and feedback from insurance intermediaries in the supply chain. IAG is aiming to build safer, stronger and more resilient communities based on customer advocacy, which leads to increased customer retention and revenue. While engaging with the community and social issues in innovative ways, IAG's shared value measurement tracks community impact and employee involvement for safer embedded communities, and sustainable business impact. Based on the Principles for Sustainable Insurance and Principles for Responsible Investment, IAG has worked with clients and business partners to raise awareness of ESG factors, resilience and infrastructural issues.

The application of shared value principles has helped IAG to collaborate and innovate based on strategic priorities as follows (Mcdougall, 2018): (1) safer at work, home and on roads, (2) business, social and natural resilience, and (3) building social resilience in communities and accessing affordable insurance solutions (Figure 1: IAG Shared Value model).

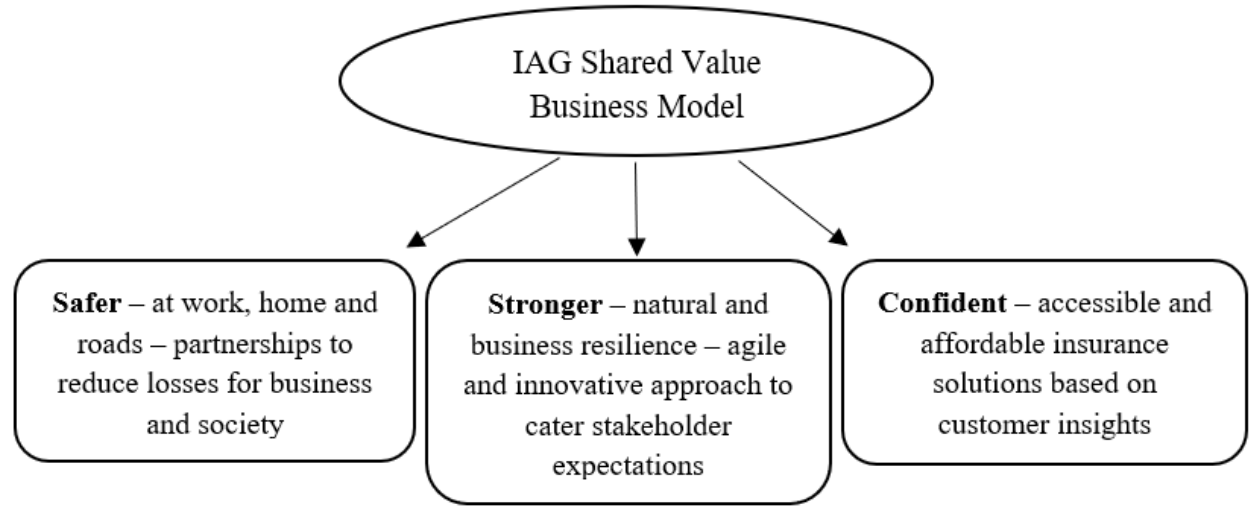

Figure 1: IAG Shared Value model (adapted from IAG 2017b, p. 1)

IAG's shared value framework (IAG, 2017b) has helped it to create safer, stronger and more confident communities. The above-mentioned shared value framework has enabled the reduction of injury during work and travel while facilitating sustainable value chain, need-based motor, content and health insurance. A comprehensive analysis of materiality issues has led to IAG's greater commitment to accessible and affordable insurance and improved customer and partner experience, climate impacts, community resilience, wellbeing and safety (IAG, 2018X).

Based on its commitment to address material issues, IAG has devised three strategic priorities (IAG, 2018x): 1) customer experience - Customer and Digital Labs for embedding innovative cloud capabilities and artificial intelligence for anticipating customers' needs and analysing behaviour, 2) modular and low-cost operating model - core technology platform for simplifying product processes and re-defining partnering network across the value chain, and 3) agile organisation with innovative skills - Leading@IAG program facilitating customers to trust 
purpose-led products/services, innovation incubator Firemark Labs bringing innovative thinking into the organisation while supporting intrapreneurs and Future ME program to improve productivity skills.

IAG describes the modus operandi of the above-mentioned strategic priorities as follows: "We continue to focus on strategic priorities of developing a safer, stronger and more confident world with an agile organisational model distinguished by customer-centric innovation" (IAG 2018a p. 4). Overall, IAG strategies (IAG 2017c) strive for sustainable procurement and investments, supply chain partnerships, customer interactions, stakeholders and civil society engagement.

The above secondary data sources demonstrate IAG's strong emphasis on organisational initiatives for shared value creation based on re-conceived products and services in general insurance. This in turn is based on a robust value chain encompassing auto repairers and research organisations. The research question sought to justify the reasoning behind these strategic value creation initiatives and the adopted general insurance framework to implement it.

\section{Secondary resource: AIA Australia Report Analysis}

AIA's ESG report describes its ongoing commitment to accountability and transparency with stakeholders (AGL, 2016a). AIA's CEO asserted that "Our fundamental belief is for a company to be commercially successful over the long-term, it must create value for both its stakeholders and for society as a whole" (AGL 2016a, p. 3). The report further noted that material aspects and reporting contents are based on three steps: (1) identification benchmarking ESG reporting practice; (2) prioritisation - stakeholder preferences and engagement; and (3) determination - ranking material issues based on stakeholder and peer analysis.

AIA Vitality is a wellness program that works on three main levels (AGL, 2016b): (1) knowing health assessment/checks for health improvement, (2) improving health - diet/nutrition/recovery plans with health partners (Vitality Institute, 2016), and (3) enjoying the rewards - savings on insurance premiums for healthy choices from AIA and its lifestyle partners (Figure 2: AIA Vitality Shared Value model).

Figure 2: AIA Vitality Shared Value model

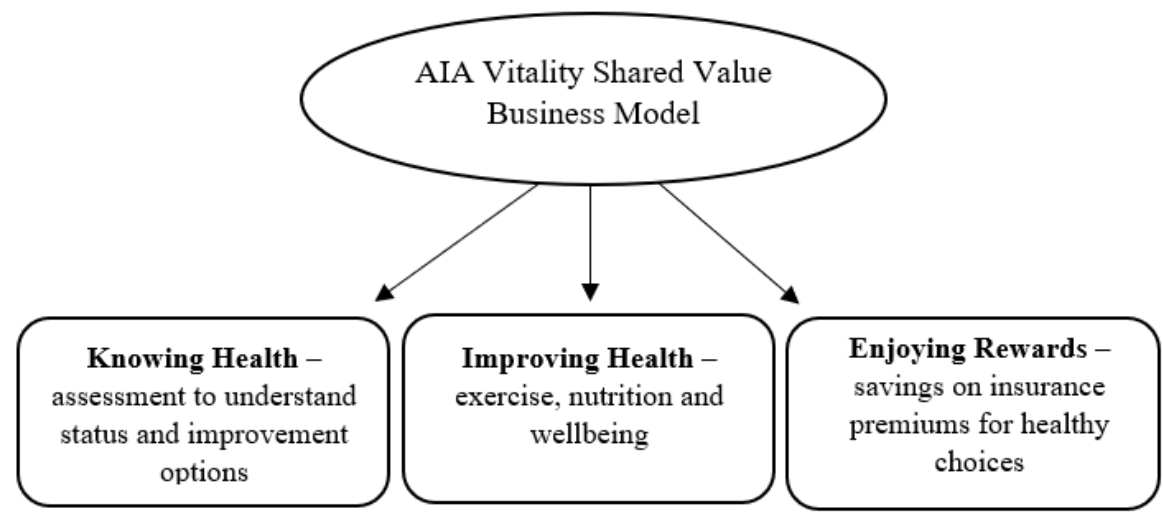

Source: Author, 2019.

The AIA Vitality, a science-based wellness program, is based on shared value principles. Economic value creation is a function of how the incentive per member generates behavioural change, while risk reduction leads to value generation and enables surplus sharing between insurer and member (AIA, 2017). This 'Vitality Program' has delivered a created value for members based on three aspects: (1) improved health and benefits for members based on incentives encompassing screening, exercise, nutrition, weight loss and rewards, (2) social benefits due to productive workforce, and (3) healthy lives leading to fewer claims and lapses for insurer while providing affordable offerings (AIA 2017, p. 2). 
A recent AIA media release, based on the AIA Healthy Living Index 2018, attracts our attention toward one-third 'financing gap' between healthcare provision and expected real costs of diabetes, cancer and heart diseases (AIA 2018). To address this effectively, the shared value model has generated two positive outcomes for AIA: (1) lower healthcare costs from diminishing claims and improved profit margins from long-living customers, and (2) supporting healthy and longer life at modest pricing for customers with improved risk profile and positive behavioural change (AIA, 2017).

The above secondary data sources demonstrate AIA's strong emphasis on organisational initiatives for shared value creation based on a value chain and collaborative health partners. The research question seeks to justify the reasoning behind these proactive strategic value creation initiatives and the adopted health insurance framework to implement it.

Based on the above-mentioned analysis of the secondary data, the interview responses are analysed to emphasise primary data.

\section{Primary Source: Interview Responses}

Five interview questions were framed to understand AIA and IAG's strategic approach toward social and economic value creation based on three thematic components of the shared value business model. A summary of the interview questions is provided (Table 1: Summary of Interview Questions).

Table 1: Summary of Interview Questions

\begin{tabular}{|l|l|}
\hline \multicolumn{1}{|c|}{ Interview Questions } & \multicolumn{1}{c|}{ Purpose of Interview Questions } \\
\hline $\begin{array}{l}\text { 1. What do you understand by sustainability and/or } \\
\text { shared value? What is the potential in your } \\
\text { organisation and industry for creating sustainable } \\
\text { and shared value? }\end{array}$ & $\begin{array}{l}\text { Obtain comparative importance and potential of } \\
\text { sustainability and shared value concepts within an } \\
\text { industry-wide environment in Australia. }\end{array}$ \\
\hline $\begin{array}{l}\text { 2. Did you re-conceive products and markets for } \\
\text { value creation? Why and how you did it? }\end{array}$ & $\begin{array}{l}\text { Obtain reason and mechanism of participating in } \\
\text { value creation based on product/service innovation }\end{array}$ \\
\hline $\begin{array}{l}\text { 3. Did you redefine productivity in the value chain or } \\
\text { cluster for value creation? Why and how you did } \\
\text { it? }\end{array}$ & $\begin{array}{l}\text { Obtain reasons and understand the mechanism of } \\
\text { participating in value creation based on collaborative } \\
\text { supply chain networks and clusters. }\end{array}$ \\
\hline $\begin{array}{l}\text { 4. Did you utilise any other component for creating } \\
\text { economic and social value? Why and how you did } \\
\text { it? }\end{array}$ & $\begin{array}{l}\text { Identify the additional components (not mentioned in } \\
\text { both sustainable and shared value models) of value } \\
\text { creation utilised by the organisations. }\end{array}$ \\
\hline $\begin{array}{l}\text { 5. Is it possible s to create social value for } \\
\text { stakeholders while maximising profit? How did } \\
\text { you balance these two conflicting interests? }\end{array}$ & $\begin{array}{l}\text { Examine the success of the sampled organisations } \\
\text { with regard to balancing shareholder and stakeholder } \\
\text { interests. }\end{array}$ \\
\hline
\end{tabular}

\section{Interview Response: Insurance Australia Group (IAG)}

Like several other participants in the insurance industry, IAG indicated that organisational social responsibility and sustainability initiatives have evolved into more strategic opportunities involving shared value principles. Hence, the IAG manager for shared value projects emphasised better economic outcomes through reduced claims, which in turn strengthened community investment to address the challenges of skills, resilience and affordability. The interviewee emphasised IAG's strategy of leveraging collaborative partnerships for value creation, with examples including the IAG Research Centre (formed in partnership with the National Motor Vehicle Theft Reduction Council) for vehicle safety design improvement, and the Cyclone Testing Centre (developed with Suncorp Bank and James Cook University) for disaster resilience. The interviewee was supportive of a healthy shared value baseline score based on measurement indicators such as public perception of safety and resilience, community safety and customer advocacy. 


\section{Interview Response: AIA Insurance}

The representative from AIA Insurance was firm in that the principles of shared value create better results than traditional corporate philanthropy. The interviewee indicated that the focus on shared value has enabled AIA to drive the business strategically and sustainably. AIA has as a result generated value for its customers, community members, suppliers, agents and other important stakeholders. The focus of AIA's shared value plan is to enable and empower people across the region to live longer, healthier and better lives. AIA believes that it can have the greatest impact by reducing claims arising from preventable conditions such as diabetes, obesity and chronic diseases. Hence, AIA has fundamentally changed its value proposition from being just a life insurer toward a health manager, closely involved in encouraging healthy lifestyle choices for Australians through incentives that include reduced premiums. The interviewee was supportive of the Responsible Investment Policy (2016), which addressed ESG factors based on feedback from investors and sustainability indices.

\section{Thematic Analysis of Interview Responses}

A thematic analysis of interview responses is conducted based on three thematic components of the shared value business model (Porter \& Kramer, 2011) as follows: (1) reconceiving product and market - upgrading value propositions to satisfy the unmet social needs of under-served customers, (2) value chain re-configuration - process efficiency, resource utilisation, sustainable procurement, logistical footprint management, and (3) enabling local clusters - collaborative infrastructure for localised production, and efficient utilisation of resources.

A categorised representation of interview responses is provided below based on thematic components of shared value model (Table 2).

Table 2: Categorisation of Interview Responses Based on Thematic Components of Shared Value

\begin{tabular}{|c|c|c|}
\hline $\begin{array}{l}\text { Shared } \\
\text { Value } \\
\text { Levels }\end{array}$ & IAG Responses & AIA Responses \\
\hline $\begin{array}{l}\text { Level 1: Re- } \\
\text { conceive } \\
\text { Products and } \\
\text { Markets }\end{array}$ & $\begin{array}{l}\text { Shifting demographic trends and the } \\
\text { introduction of new technology has } \\
\text { fundamentally changed the nature of the } \\
\text { insurance market and our products. } \\
\text { Our business' strategy is focused on affordable } \\
\text { and customer-centric product and service } \\
\text { offerings, while delivering strong underlying } \\
\text { profitability by focusing on pricing and } \\
\text { underwriting disciplines. } \\
\text { Our value proposition is to make your world a } \\
\text { safer place by providing justified claims in time } \\
\text { of need. } \\
\text { Our shared value approach has helped us to } \\
\text { deliver on our purpose in a way that drives } \\
\text { commercial value for our employees, partners } \\
\text { and shareholders. }\end{array}$ & $\begin{array}{l}\text { We are addressing obesity and life style related } \\
\text { diseases alongside chronic diseases in advance to } \\
\text { grab the opportunity of market expansion. } \\
\text { The primary focus of our product offering (both } \\
\text { Vitality and Rehabilitation) is healthy living by } \\
\text { proactive empowering by meeting personal health } \\
\text { goals through exercise, food, and check-ups. } \\
\text { The main motto is to help people live longer with } \\
\text { healthier and better lives. } \\
\text { A unique preventative and conscious health and } \\
\text { wellbeing proposition has enabled us to gain } \\
\text { competitive advantage. } \\
\text { It is estimated that every dollar spent on } \\
\text { (rehabilitation program) supporting with mental } \\
\text { health issues yielded five times return. }\end{array}$ \\
\hline $\begin{array}{l}\text { Level 2: } \\
\text { Redefine the } \\
\text { Value Chain }\end{array}$ & $\begin{array}{l}\text { We have strengthened our networking with } \\
\text { limited number of repairers, which enabled us in } \\
\text { turn to deliver high quality repairs at costs that } \\
\text { are more competitive. }\end{array}$ & $\begin{array}{l}\text { Our strong platform is based on our proprietary } \\
\text { agency, Supplier Code of Conduct and supply } \\
\text { chain partnership, distribution channels while } \\
\text { successfully reducing claims. }\end{array}$ \\
\hline $\begin{array}{l}\text { Level 3: } \\
\text { Enable } \\
\text { Local } \\
\text { Cluster } \\
\text { Developmen } \\
\text { t: }\end{array}$ & $\begin{array}{l}\text { We have collaborated with Good Shepherd } \\
\text { Microfinance, Consumer Action Law Centre, } \\
\text { and Community Legal Centres to explore the } \\
\text { issue of insurance affordability and } \\
\text { accessibility. } \\
\text { Our innovation strategy has helped us in cost } \\
\text { reduction and product management. }\end{array}$ & $\begin{array}{l}\text { Based on academic and industry collaboration, we } \\
\text { have screened people with mental health issues, } \\
\text { and provided advisory support in restoring } \\
\text { individual and organisational confidence. } \\
\text { AIA Accelerator has set off to pioneer the next- } \\
\text { generation corporate innovation by insuring high } \\
\text { potential start-ups. }\end{array}$ \\
\hline
\end{tabular}




\begin{tabular}{|l|l|l|}
\hline $\begin{array}{c}\text { Shared } \\
\text { Value } \\
\text { Levels }\end{array}$ & \multicolumn{1}{|c|}{ IAG Responses } & AIA Responses \\
\hline & $\begin{array}{l}\text { We have partnered with community } \\
\text { organisations, universities, and government for } \\
\text { disaster preparedness and regional development. }\end{array}$ & $\begin{array}{l}\text { The focus of our offering is proactive empowering } \\
\text { such as meeting personal health goals through } \\
\text { exercise, food, and check-ups for people across the } \\
\text { regional communities to live healthier lives. }\end{array}$ \\
\hline
\end{tabular}

The analysis of interview responses based on the three thematic components of the shared value model demonstrates that both the sampled insurance organisations preferred to leverage the shared value model for value creation, as illustrated through comments below.

\section{Utilisation of Shared Value Business Model: IAG and AIA Insurance}

Porter and Kramer (2011) proposed a three-level shared value model (i.e. product/market, value chain, and cluster) with the aim of changing the organisational value proposition to create a competitive advantage. The following interview responses indicated the organisations approach to the shared value model.

As Australia's first corporate shared value team, we have developed a shared value model outlining our commitment to creating a safer, stronger and confident community. [IAG]

Our recent positive shared value approach to health awareness, wellness and rehabilitation helps the working community members to get back to work quickly while reducing insurance claims. [AIA]

Based on inclusive value propositions, shared value capabilities are increasingly being utilised by the sampled Australian insurance organisations for value-embedded benefits as follows: (1) spreading health consciousness by understanding and tracking health trends for wellbeing to reduce insurance claims; (2) chronic health management and rehabilitation to increase productivity; (3) application of modern technology to increase safety at work and on roads; and (4) instilling behavioural and communal changes to enhance resilience.

To facilitate the understanding of value creation, the financial and sustainability profiles, strategic initiatives, and organisational statements of AIA is presented below (Table 3).

Table 3: AIA Australia Profile and Strategic Initiatives for Value Creation

\begin{tabular}{|c|c|}
\hline $\begin{array}{l}\text { Designated } \\
\text { Authority for } \\
\text { Value Creation }\end{array}$ & Respondent 1, Manager, Corporate Communications \\
\hline $\begin{array}{l}\text { Profile of } \\
\text { Insurance } \\
\text { Organisation - } \\
\text { Financial and } \\
\text { Sustainability }\end{array}$ & $\begin{array}{l}\text { Organisational Information (AIA Group, 2017y): } \\
\text { - } \quad \text { presence in } 18 \text { markets in Asia-Pacific with total } 16 \text { million members with } \\
\text { total sum assured US\$1 trillion for group insurance schemes; and } \\
\text { - } \quad \text { working closely with major financial institutions, financial advisors, } \\
\text { superannuation funds, and corporate partners - catering for long term savings } \\
\text { and protection needs, employee benefits, and life-accident-health insurance } \\
\text { services } \\
\text { Financial Profile (AIA Group, 2017y): } \\
\text { - } \text { engaging people in healthier lifestyles while profitably serving more than } 30 \\
\text { million policy holders across Asia-Pacific region; } \\
\text { leading life insurance company protecting the health and wellbeing of more } \\
\text { than } 3.5 \text { million Australians; } \\
\text { second largest insurer in the world made } 13 \text { million benefit payments during } \\
\text { 2017 and IFRS operating profit after tax grew by } 16 \text { per cent; } \\
\text { acquisition of life insurance business (Comm Insure) in Australia and life and } \\
\text { health insurance business (Sovereign Assurance Company) in New Zealand of }\end{array}$ \\
\hline
\end{tabular}




\begin{tabular}{|c|c|}
\hline $\begin{array}{l}\text { Designated } \\
\text { Authority for } \\
\text { Value Creation }\end{array}$ & Respondent 1, Manager, Corporate Communications \\
\hline & $\begin{array}{l}\text { Commonwealth Bank of Australia (2017) along with new } 20 \text { years strategic } \\
\text { bancassurance distribution agreements in both markets with a combined base } \\
\text { of } 13 \text { million customers; and } \\
\text { - AIA Vitality - impacting seven million lives in } 15 \text { international markets } \\
\text { through the Global Vitality Network - membership increased more than three } \\
\text { times in } 2017 \text { with more than 700,000 full membership customers of wellness } \\
\text { programs } \\
\text { Sustainability Profile (AIA Group, 2017x): } \\
\text { - } \quad \text { over \$5 million contributed to community programs and } 1.5 \text { million } \\
\text { beneficiaries to our community programs; } \\
\text { - included in FTSE4Good index for the first time in } 2017 \text {; } \\
\text { - included on the 2018 Bloomberg Gender Equality Index; and } \\
\text { invested \$22 billion in infrastructure-related sectors such as electricity, } \\
\text { transportation and telecommunications }\end{array}$ \\
\hline $\begin{array}{l}\text { Value Creation } \\
\text { Initiatives and } \\
\text { Outcomes }\end{array}$ & 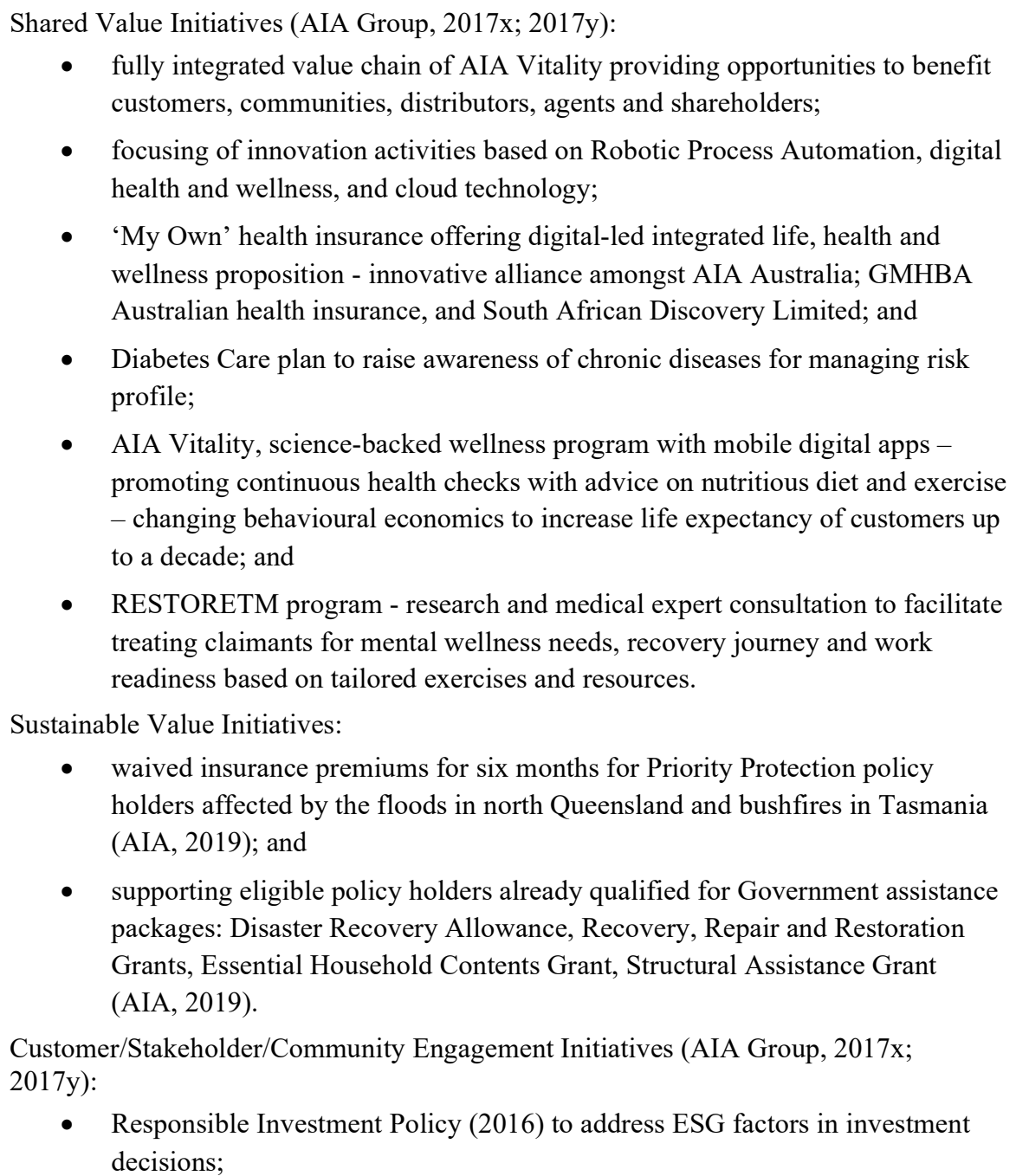 \\
\hline
\end{tabular}




\begin{tabular}{|c|c|}
\hline $\begin{array}{l}\text { Designated } \\
\text { Authority for } \\
\text { Value Creation }\end{array}$ & Respondent 1, Manager, Corporate Communications \\
\hline & $\begin{array}{l}\text { - digital health/wellness, artificial intelligence, cloud technology and blockchain } \\
\text { innovation for deeper analysis of customer preferences, and consumer } \\
\text { behaviours enable AIA to meet the individually-tailored needs of our } \\
\text { customers } \\
\text { - My Page (2017) - next generation customer platform, offering an integrated } \\
\text { online and mobile, single digital touchpoint, consistently linking customers } \\
\text { with all products and services; and } \\
\text { - expanding presence on third-party online platform WeChat - facilitating } \\
\text { information service, appointment booking and e-claims within four days }\end{array}$ \\
\hline $\begin{array}{l}\text { Statements in } \\
\text { Organisational } \\
\text { Report Supporting } \\
\text { Facilitation of } \\
\text { Value Creation }\end{array}$ & $\begin{array}{l}\text { Statements in support of thematic components of sustainable and shared value creation: } \\
\text { "There are opportunities in evolving lie and health insurance, moving from the } \\
\text { traditional transactional model to one for helping customers to prevent the onset of } \\
\text { illness by encouraging long-term beneficial lifestyle changes. We are driving economic } \\
\text { and social development demonstrating a truly shared value business model" (AIA } \\
\text { Annual Report, 2016; p. } 21 \text { ); } \\
\text { "We continue to execute our growth strategy to create long-term sustainable value for } \\
\text { our shareholders" (AIA Annual Report, 2017; p. 13); } \\
\text { "The delivery of sustainable value and is essential to maintaining a culture of business } \\
\text { integrity and investor confidence" (AIA Annual Report, 2017; p. 92); }\end{array}$ \\
\hline
\end{tabular}

AIA Vitality, the most successful shared value initiative of AIA Australia, creates value through a threefold strategy (Figure 3: Member Value Creation through AIA Vitality Insurance): (1) members wellbeing (improved health at a better price), (2) social development (healthier society), and (3) insurer (lower claims and lapses). The AIA value creation framework is facilitating all three stakeholders - members, society and insurer.

Figure 3: Member Value Creation through AIA Vitality Insurance

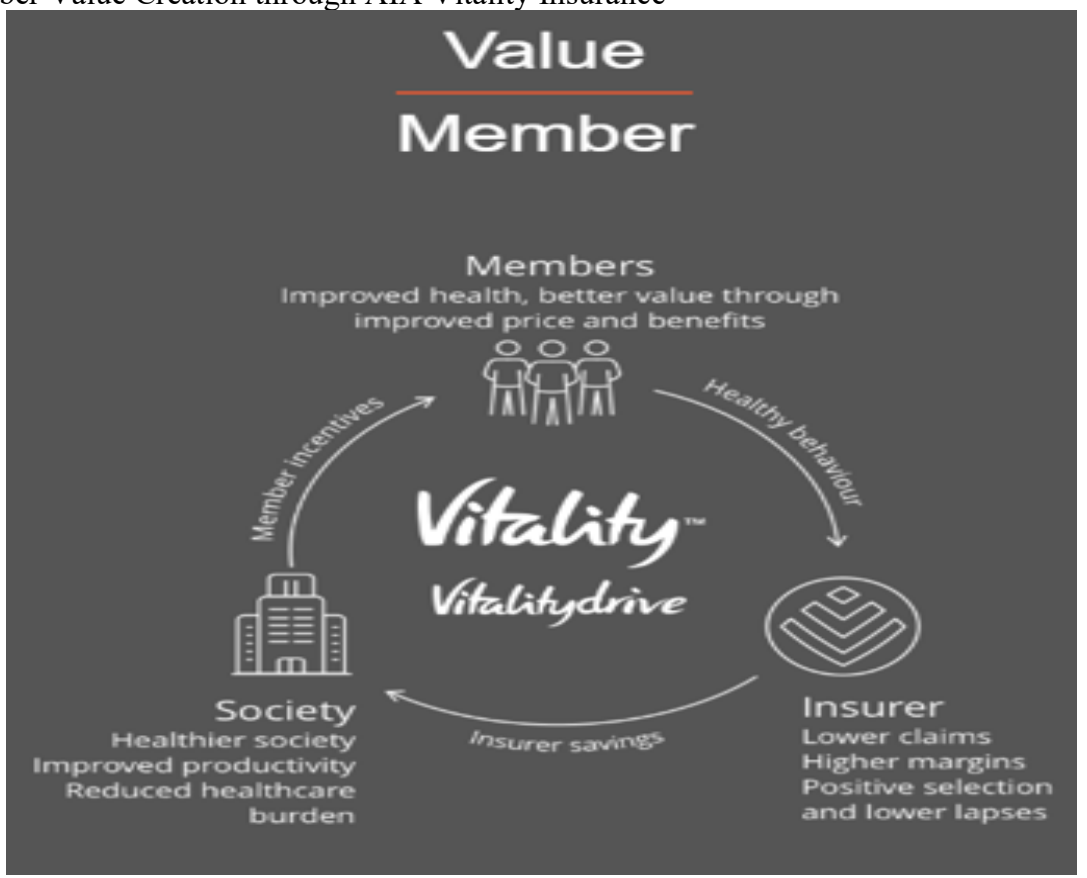

Source: AIA 2017, p. 2. 
Like AIA, IAG has also adopted the shared value initiatives and thus, promoting shared value aspects of product/process innovation alongside clustered collaboration throughout the supply chain encompassing stakeholders and communities. For making the world a safer place, IAG adopted a threefold shared value strategy: (1) enhancing customer experience (data analysis), (2) simplified operational model (supply chain partnership), and (3) agile organisational innovation and skilling (purpose driving future workforce).

To facilitate the understanding of value creation, the financial and sustainability profiles, strategic initiatives, and organisational statements of IAG is presented below (Table 4).

Table 4: IAG Profile and Strategic Initiatives for Value Creation

\begin{tabular}{|c|c|}
\hline $\begin{array}{l}\text { Designated } \\
\text { Authority for Value } \\
\text { Creation }\end{array}$ & Respondent 2, Innovation Manager, Shared Value \\
\hline $\begin{array}{l}\text { Profile of Insurance } \\
\text { Organisation - } \\
\text { Financial and } \\
\text { Sustainability }\end{array}$ & $\begin{array}{l}\text { Organisational Information (IAG, 2018x): } \\
\text { - IAG competitive portfolio (NRMA, CGU, SGCI, SGIO, WFI) based on acquisition- } \\
\text { centric growth strategy by acquiring AMI NZ in 2012, and Wesfarmers insurance in } \\
\text { 2014; and } \\
\text { - } \quad \text { insuring one in four car and/or homes } \\
\text { Financial Profile (IAG, 2018x): } \\
\text { - gross written premium up 1.8\%; } \\
\text { - reported insurance margin and cash return on equity close to 15\%; } \\
\text { - double-digit insurance profit and regulatory capital } \\
\text { Sustainability Profile: } \\
\text { - good performance in the DJSI World, Asia Pacific and Australia indices in 2015-16 }\end{array}$ \\
\hline $\begin{array}{l}\text { Value Creation } \\
\text { Initiatives and } \\
\text { Outcomes }\end{array}$ & $\begin{array}{l}\text { Shared Value Initiatives (IAG, 2018x): } \\
\text { - Shared Value Measurement tracks eight measurement indicators - perception of safety } \\
\text { and resilience of people, safety of communities, customer advocacy etc. - baseline score } \\
\text { of more than 50\%; } \\
\text { - flexible single item insurance called 'Insurance } 4 \text { That' - IAG in conjunction with Good } \\
\text { Shepherd Microfinance (IAG 2016b); } \\
\text { - Insure Lite - low-cost home building insurance covers the home, excluding sheds and } \\
\text { pools, for damage greater than \$3950 (IAG 2016a); } \\
\text { 10\% premium discount for NRMA Insurance customers with fuel-efficient car and } \\
\text { collision avoidance technology; } \\
\text { - } \text { Eco Smash Program - repairers to comply with good environmental practices; } \\
\text { - Supplier Governance Framework - real-time data from more than half million sources to } \\
\text { monitor risk exposure across our global supply chain; } \\
\text { - IAG Research Centre, partnership with National Motor Vehicle Theft Reduction } \\
\text { Council - - vehicle safety-testing, design improvement, upgrading head restraint } \\
\text { mechanisms, and theft reduction; } \\
\text { - } \text { safety improvements to an entrance ramp on the M4 at Silverwater, reducing the } \\
\text { number of collisions at this blackspot by around } 300 \text { per year and saving an estimated } \\
\text { \$600,000 per year in claim costs since 2005; } \\
\text { - } 10 \text {-years partnership with iMOVE Australia - insights into the future of connected } \\
\text { transport; } \\
\text { Suncorp and James Cook University Cyclone Testing Centre - collaboration to } \\
\text { understand the cost of claims and community resilience after cyclones; } \\
\text { CGU partnering with Catalysr - start-up incubator for refugee and migrant } \\
\text { entrepreneurs in Blacktown; } \\
\text { - }\end{array}$ \\
\hline
\end{tabular}




\begin{tabular}{|c|c|}
\hline $\begin{array}{l}\text { Designated } \\
\text { Authority for Value } \\
\text { Creation }\end{array}$ & Respondent 2, Innovation Manager, Shared Value \\
\hline & 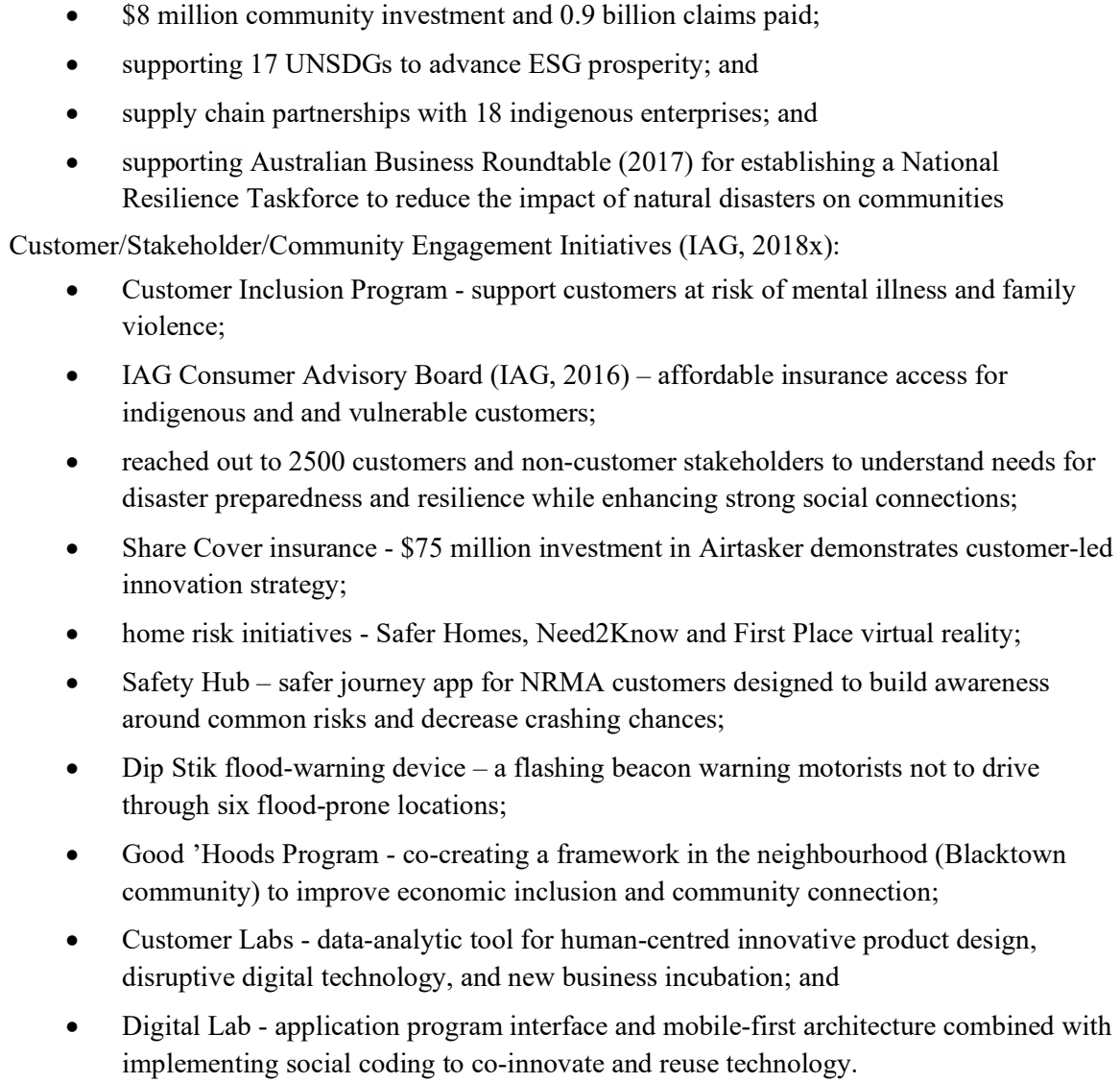 \\
\hline $\begin{array}{l}\text { Statements in } \\
\text { Organisational } \\
\text { Report Supporting } \\
\text { Facilitation of Value } \\
\text { Creation }\end{array}$ & $\begin{array}{l}\text { Statements by Suncorp in support of thematic components of sustainable and shared value } \\
\text { creation: } \\
\text { "IAG's strategy and performance on social and environmental issues are actively set and } \\
\text { monitored by our Shared Value Advisory Council, with input from forums such as the IAG Ethics } \\
\text { Committee" (IAG, 2017X, p. 4); } \\
\text { "We seek to create commercial value alongside positive societal outcomes by strategically } \\
\text { pursing work on important topics aligned to our Shared Value Framework" (IAG, 2017X, p. 2); } \\
\text { "We prioritise our work based on the significance of aspects, alignment to our strategy and shared } \\
\text { value approach, and the perspectives of key stakeholders" (IAG, 2017X, p. 3); } \\
\text { "We pursue opportunities to improve social and environmental performance in our value chain } \\
\text { and sphere of influence. This includes through our procurement, supply chain, investments, } \\
\text { partnerships and interaction with customers, as well as through our engagement with government } \\
\text { and civil society" (IAG, 2017X, p. 3); } \\
\text { IAG's Code of Ethics \& Conduct and People-related Policies support on a range of topics, } \\
\text { including health, safety and wellbeing; diversity, inclusion and working conditions (IAG, 2017X, } \\
\text { p. } 3 \text { ); } \\
\text { "Stakeholder dialogue is essential for us to respond to the expectations of the community about } \\
\text { how we manage our social and environmental impacts and to share our insights on risk } \\
\text { management with the community" (IAG, 2017X, p. 4); } \\
\text { "We engage internal and external stakeholders and communities on opportunities to create value } \\
\text { for our customers, shareholders, people, partners and our community" (IAG, 2017X, p. 4); } \\
\text { "Our Board has overarching responsibility for shared value and sustainability, with our internal } \\
\text { Shared Value Advisory Council providing advice and input" (IAG, 2018x; p. 14); }\end{array}$ \\
\hline
\end{tabular}




\begin{tabular}{|l|l|}
\hline $\begin{array}{l}\text { Designated } \\
\text { Authority for Value } \\
\text { Creation }\end{array}$ & Respondent 2, Innovation Manager, Shared Value \\
\hline & $\begin{array}{l}\text { "We apply our shared value principles to help our own business by improving community } \\
\text { connections and resilience while reducing risk and claims through collaborative community } \\
\text { partnerships" (IAG, 2018x; p. 2); and } \\
\text { "Building on shared value innovation and supply chain management, we are developing and } \\
\text { adapting products, services and business models that deliver commercial, customer and } \\
\text { community advantage. By addressing community preparedness, insurance access, and insurance } \\
\text { affordability, we aim to achieve our mutual objectives to make communities safer and more } \\
\text { resilient, so they can thrive" (IAG, 2018x; p. 14). }\end{array}$ \\
\hline
\end{tabular}

IAG strategy is based on the three major aspects as follows (Refer Figure 4: IAG Strategy): (1) customer - data analytics and digital innovation to enhance customer experience, (2) simplification - supply chain partnering for low-cost operational model, and (3) agility - agile organisation developing skilled future workforce.

Figure 4: IAG Strategy

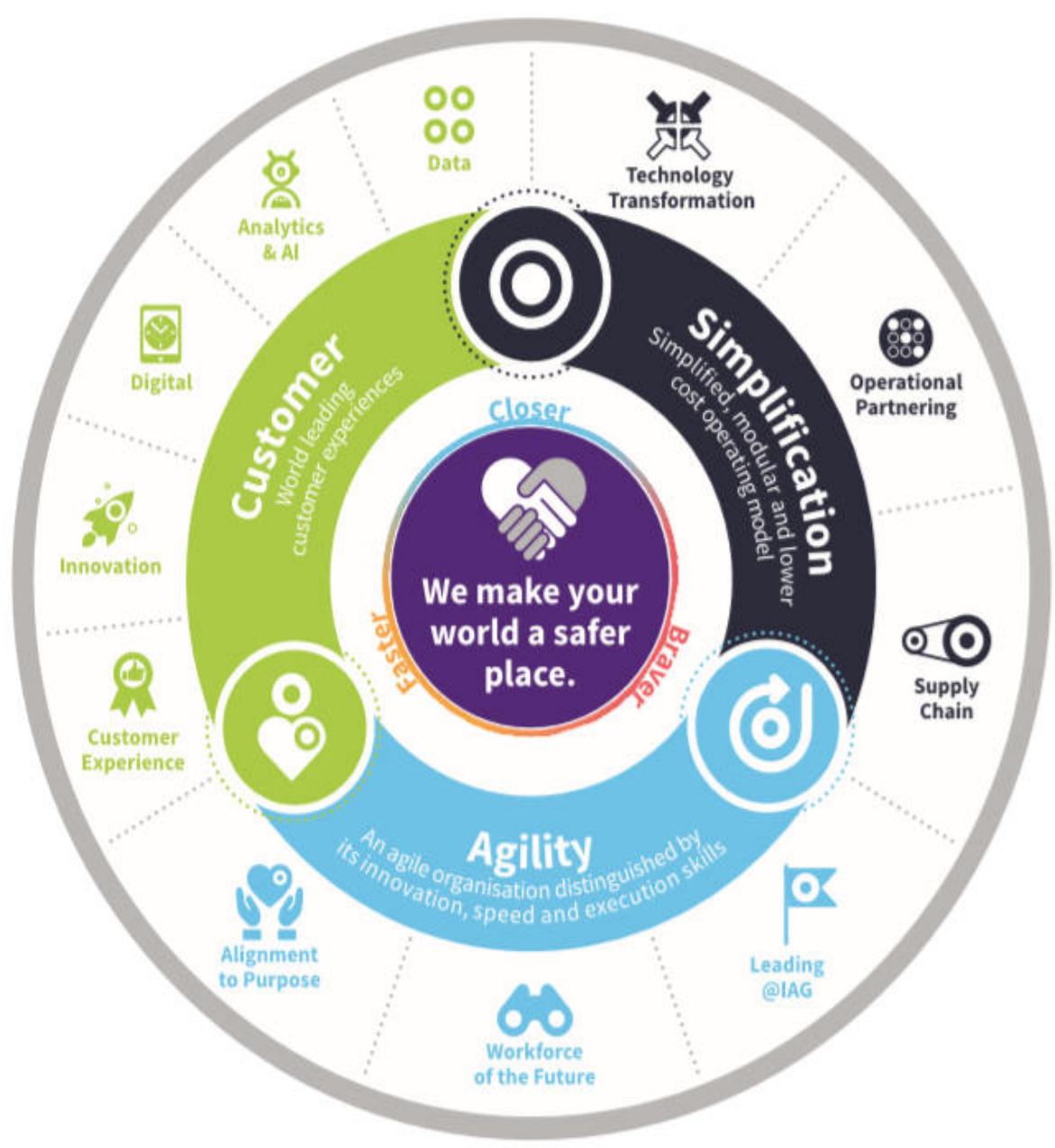

Source: IAG, 2018x. 
In spite of the strategic shared value initiatives, the organisational shared value creation can be evaluated from a critical perspective. In a practical business world, most of the sustainable initiatives require mid- to long-term approaches to realise economic value. However, the shared value model has produced positive outcomes for IAG and AIA, in terms of both profitability and market expansion. The reported insurance margin of IAG increased from $15.5 \%$ (FY 2017) to $18.3 \%$ (FY 2018) [IAG 2018]. AIA has also saw an increase (1\%) in operating profit after tax over the same period. Simultaneously, both organisations have created social value for the community. While both have failed to cater to the bottom of the pyramid market, leaving 3.5 million excluded customers, both have attempted to adopt a need-based, customised strategy to popularise insurance.

\section{Discussion of the Research Question: Why and How Have Australian Insurance Organisations Integrated 'Shared Value' Model Into Their Core Business?}

Based on the secondary (organisational reporting) data and primary (interview response) data, it appears that IAG has integrated 'shared value' model into its core business with specific motives and frameworks. There are numerous strategic initiatives to facilitate shared value creation. For example, in catering to customers' needs through its Customer and Digital Labs, IAG has leveraged three aspects - safer, stronger, and more confident communities. IAG's collaborative partnerships are notable in the auto and home/content insurance sector for facilitating infrastructural and resilience issues. In addition, IAG has utilised a core technology platform (Customer and Digital Labs) to simplify product processes while redefining its partner network across the value chain. To increase affordable insurance access for vulnerable customers, the IAG Consumer Advisory Board (2016) has promoted a flexible single-item insurance called 'Insurance 4 That'. Finally, IAG has shown a strong commitment to community resilience based on the Good Hoods neighbourhood program and establishment of a National Resilience Taskforce.

Similarly, the primary and secondary data indicate that AIA Australia has integrated 'shared value' model into its core business. AIA has adopted a shared value approach to pursue policy-holders' aspirations to a stronger and healthier society and a productive workforce, and this approach has enhanced their profitability through reductions in claims. Again, there are numerous strategic initiatives facilitating shared value creation. 'My Own' health insurance offers a digital-led integrated life, health and wellness proposition to motivate people to lead healthier, longer and better lives. AIA has facilitated the health insurance industry based on My Page (2017) customer engagement platform and RESTORE program for medical expert consultation of treating claimants. Finally, the unique wellness program, AIA Vitality, has facilitated behavioural changes for customer value creation as well as strengthening the financial bottom line for the organisation.

Shared value application in insurance is about creating health and safety management through community investments and infrastructural development, rather than conventional post-event incident management. IAG, being a non-life and non-health insurer, focuses on collaborative efforts to create safer, stronger and more resilient communities, while AIA Australia emphasises reduction of physical and mental health claims through vitality, wellness and rehabilitation programs.

\section{Conclusion}

The selected insurance organisations are striving to respond to social issues by leveraging on a shared architecture and collaborative stakeholder ecosystem. They are creating shared value in a sustainable way based on a various thematic component emphasising two broad aspects, which are 1) having a unique proposition of value-embedded products and services, and 2) re-defining value chain and clusters to expand the interface with customers and stakeholders. There is no doubt that the Australian insurance industry is investing in community health, safety and wellbeing to create long-term value. The value creation strategies of IAG and AIA focus on proactive approaches to situational development before adverse incidents occur. In summary, it is evident that AIA and IAG have both created opportunities for value creation based on: 1) creating proactive awareness of health and safety based on value chain partnerships, and 2) encouraging wellbeing activities while delivering customised products and services. Thus, Australian insurance organisations are simultaneously creating social value for the community while enhancing economic value for the organisation.

The study suggests that both the selected Australian insurers (i.e. AIA, IAG) have started to undertake riskier community projects to integrate more than three million excluded population. In order for Australian insurance organisations to create both social and economic value at scale, it is recommended that co-creative value propositions for customer and stakeholder engagement need to be integrated in the early planning and designing 
stages within the industrial ecosystem. Hence, Australian regulators (Reserve Bank of Australia, Australian Prudential and Regulatory Authority and Australian Securities and Investment Commission) and designated authorities (Australian Competition and Consumer Commission) should be tasked with assessing the expected effects of competition for delivering customised value-embedded insurance products and services. The findings of the study would facilitate a greater intellectual discussion in the field of community development based on a new insurance value proposition to further support the health and safety of Australians.

\section{REFERENCES}

Accenture. 2017. Insurance Change Survey. http://ins.accenture.com/rs/897-EWH-515/images/AccentureFinancial-Services-Change-Survey-2017-Insurance-Report-POV.pdf

AAI Limited. 2015. Good Cover, Simple Options. https://www.essentialsbyaai.com.au/insurance/

AIA Group Limited. 2016a. Environmental, Social and Governance Report. http://www.aia.com/content/dam/group/en/esg/esg-report-2016-eng.pdf

AIA Group Limited .2016b. AIA Vitality. https://www.aiavitality.com.au/vmp-au/

AIA Group Limited. 2017. AIA Vitality Shared Value Insurance. http://sharedvalueinsurance.com/

AIA Group (2017x). Environmental, Social and Governance Report. Retrieved from http://www.aia.com/content/dam/group/en/esg/esg-report-2017-eng.pdf

AIA Group (2017y). Annual Report 2017 - Shaping Our Future. Retrieved from https:/www.aia.com/content/dam/group/en/docs/annual-report/aia-annual-report-2017-eng.pdf

AIA Group Limited. 2018. AIA Healthy Living Index 2018 Shows 'Financing Gap' Between Healthcare Provisions and Expected Real Costs of Serious Illness. Media Release. http://www.aia.com.au/en/individual/about-aia/media-centre/press-releases/2018/aia-healthy-living-index-2018shows-financing-gap.html

AIA Australia (2019). AIA Announces Premium Waiver for Flood, Bushfire Victims. Retrieved from http://www.aia.com.au/en/individual/about-aia/media-centre/press-releases/2019/AIA-announces-premiumwaiver-for-flood-bushfire-victims.html

Australian and New Zealand Institute of Insurance and Finance (2019). Top five insurance industry trends for 2019. Retrieved from https://anziif.com/members-centre/articles/2019/03/top-five-insurance-industry-trends-for$2019 ? \mathrm{p}=1 \& \mathrm{mbs}=\& \mathrm{cat}=$ all

Australian Securities and Investments Commission (ASIC). 2017. National Financial Literacy Strategy: Annualfina Highlights Report 2016-17. http://www.financialliteracy.gov.au/media/560953/nfls-annualhighlights-report-16-17.pdf

Christie, G., Patrick, K., and Yach, D. 2016. Guidelines for Personalized Health Technology: Final Report. New York NY: Vitality Institute.

Ernst \& Young. 2017. Asia Pacific Insurance Outlook. http://www.ey.com/g1/en/industries/financialservices/insurance/ey-asia-pacific-insurance-outlook

Gibson, J. G. and Brown, A. (2009). Working with Qualitative Data. London: Sage.

Gore, A. 2015. "How Discovery Keeps Innovating." McKinsey Quarterly 1-3. https:/www.mckinsey.com/industries/healthcare-systems-and-services/our-insights/how-discovery-keepsinnovating

Hems, L., \& Leth, M. (2013). Leading Australian companies creating shared value. Retrieved from http://www.3pillarsnetwork.com.au/wp-content/uploads/2013/11/Melinda-Leth-Presentation-

V1_261113_Final.pdf

IAG (Insurance Australia Group). 2016a. Insure Lite. https://www.insurelite.com.au/\#/index

IAG (Insurance Australia Group). 2016b. Insurance 4 That Product Disclosure Statement. https://www.insurance4that.com.au/assets/pdf/Insurance4That-PDS.pdf 
IAG (Insurance Australia Group). 2017a. A Safer Future: Annual Review and Sustainability Report 2017. https://www.iag.com.au/sites/default/files/Documents/Results\%20\%26\%20reports/2017-annual-reviewsustainability-report.pdf

IAG (Insurance Australia Group). 2017b. Creating Shared Value. https://www.iag.com.au/shared-value/creatingshared-value

IAG (Insurance Australia Group). 2017c. Group Social and Environmental Policy. https://www.iag.com.au/sites/default/files/Documents/Business\%20sustainability/IAG-Social-and-

Environmental-Policy-August-2017.pdf

IAG Insurance Australia Group (2017x). Group Social \& Environmental Policy. Retrieved from https://www.iag.com.au/sites/default/files/Documents/Business\%20sustainability/IAG-Social-and-

Environmental-Policy-August-2017.pdf

IAG (Insurance Australia Group). 2018a. "IAG Announces 1H18 Results." Media Release. https://www.iag.com.au/sites/default/files/Documents/Results\%20\%26\%20reports/1H18-media-release.pdf

IAG (Insurance Australia Group). 2018b. Our Commitments. https://www.iag.com.au/shared-value/ourcommitments

IAG Insurance Australia Group (2018x). Annual review and safer communities report 2018: Being guided by our purpose helps us make your world a safer place. Retrieved from https://www.iag.com.au/sites/default/files/Documents/Results\%20\%26\%20reports/2018-annual-review-andsafer-communities-report.pdf

Insurance Council of Australia. 2017. Productivity Commission Inquiry: Competition in the Australian Financial System. https://www.pc.gov.au/_data/assets/pdf_file/0003/221979/sub032-financial-system.pdf

Jais, N., Flynn Lund, F., Pfitzer, M., and Rodriques, A. 2017. Insuring Shared Value: How Insurers Gain Competitive Advantage by Better Addressing Society's Needs. https://www.sharedvalue.org/sites/default/files/resource-files/Insuring\%20Shared\%20Value_7-5-17.pdf

Kania, J., and Kramer, M. 2011. Collective Impact. Retrieved from https://ssir.org/images/articles/2011_WI_Feature_Kania.pdf

Kramer, M. R., and Pfizer, M. W. 2016. The Ecosystem of Shared Value. https://hbr.org/2016/10/the-ecosystemof-shared-value

Maltz, E., \& Schein, S. 2012. “Cultivating Shared Value Initiatives: A Three Cs Approach.” Journal of Corporate Citizenship 47: 55-74.

Mcdougall, L. 2018. Australian Shared Value in the Insurance Industry. https://www.sharedvalue.org/groups/australian-shared-value-insurance-industry

McKinsey \& Company. 2015. How Discovery Keeps Innovating. https://www.mckinsey.com/industries/healthcare-systems-and-services/our-insights/how-discovery-keepsinnovating

Pfitzer, M., Bockstette, V. and Stamp, M. 2013. "Innovating for Shared Value.” Harvard Business Review 91: $100-107$.

Pirson, M. 2012. "Social Entrepreneurs as the Paragons of Shared Value Creation? A Critical Perspective." Social Enterprise Journal 8(1): 31-48.

Porter, M. E. and Kramer, M. R. 2006. "Strategy and Society: The Link Between Competitive Advantage and Corporate Social Responsibility.” Harvard Business Review 84 (12): 78-92.

Porter, M. E., and Kramer, M. R. 2011. “The Big Idea: Creating Shared Value: Rethinking Capitalism.” Harvard Business Review 89 (1-2): 62-77.

Prahalad, C.K., and Ramaswamy, V. (2004). The Future of Competition. Boston MA: Harvard Business School Press.

PwC. 2017. Escaping the Commodity Trap and the Future of Banking in Australia. https://www.pwc.com.au/pdf/pwc-report-future-of-banking-in-australia.pdf

Scott, M. (2019, Septermber 25). APRA warning: natural disasters a growing risk. The Australian, p. 21. 
Shared Value Project. 2015. Shared Value Delivers Social and Economic Benefits for Australia. http://sharedvalue.org.au/wp-content/uploads/2015/08/2015-Shared-Value-Survey-Press-Release.pdf

Stavros, C. and Westberg, K. 2009. "Using Triangulation and Multiple Case-studies to Advance Relationship Marketing Theory." Qualitative Market Research: An International Journal 12 (3): 307-320.

Verboven, H. (2011). Communicating CSR and Business Identity in the Chemical Industry through Mission Slogans. Business Communication Quarterly, 74(4), 415-431.

Vitality Institute. 2016. Reporting on Health: A Roadmap for Investors, Companies, and Reporting Platforms. http://thevitalityinstitute.org/site/wp-content/uploads/2016/01/Vitality-

HealthMetricsReportingRoadmap22Jan2016.pdf

Wu, T. (2017). “General Insurance in Australia.” IBISWorld Industry Report (August), K6322.

Yin, R. K. (2009). Case Study Research Design and Methods ( $4^{\text {th }}$ edn). Thousand Oaks: Sage. 